\title{
ARCHITECTURE AS A TEXTUAL PHENOMENON: ALEXANDER BRODSKY'S ARCHITECTURAL PRACTICES OF APPROPRIATION
}

\author{
A B S T T R A C T
}

This paper analyses architecture created through appropriating existing materials while focusing on strategies of intertextuality. It argues that the meaning of an architectural object does not derive from itself, or its poetic concepts, but rather from its relationship with other architectural objects, other art works as texts, cultural texts, and everyday practices. My aim is to show various theoretical problems of the theory of architecture and art, which as a network of overlapping texts of culture, surround the architectural production of Alexander Brodsky. Here I use different and varied theoretical concepts, selecting two case studies by Brodsky - The Pavilion for Vodka Ceremonies and Rotunda - upon which the paper is based as an interdiscursive study.

\section{Boško Drobnjak}

University of Belgrade - Faculty of Architecture 
INTRODUCTION

'It is self-evident that nothing concerning art is self-evident anymore, not its inner life, not its relation to the world, not even its right to exist.'

Theodor Adorno

Alexander Brodsky (1955) is an artist and architect. In 1978, he graduated from Moscow Architecture Institute, and he was a member of the Russian's group Paper Architects in the 1980s, working alongside the architect, Ilya Utkin $^{2}$. Apart from Brodsky and Utkin, the leading figures in this group were Michael Belov, Mikhail Filippov, Nadia Bronzova and Yuri Avvakumov. ${ }^{3}$ Visionary (also paper) architecture is the name given to the architecture that exists only in the form of a drawing, referring to utopian, dystopian or fantasy projects or concepts. For Brodsky and Utkin, paper architecture provided an ideological segregation from the Soviet government and monotonous Soviet architecture at that time. ${ }^{4}$ Brodsky moved to New York to work on public projects and art installations in 1996. ${ }^{5}$ Most of Brodsky's architectural projects were realised upon his return to Moscow after $2000 .{ }^{6}$

I will here deal with appropriation as the main method in Brodsky's architectural practice. His use of found materials, window frames, door frames, etc., sets several theoretical problems in the context of period and set of ideas after postmodern socialist architecture ${ }^{7}$ that will be discussed further.

At its core, this paper collects the traces of many discursive voices of the theory of art and architecture. My aim is not to analyse and present the poetics and concepts of Brodsky's experimental practices in their singularity, but to display the other to the literal material appearance of its architecture. The fundamental theoretical position of this paper relies on the theoretical platforms of Roland Barthes and Julia Kristeva (poststructuralism), who point out that we never see the things themselves or the objects/items/buildings themselves, but the objects in the context of all the processes of cultural relations that give an object a value, meaning and a function. This implies a mesh of reading and transferring of meanings that interact with each other changing their places and roles, and it is in the overlapping of these readings that we recognise an artwork as a construction, which means that the artwork (building) does not exist as a matter in itself. 
The assumption I am making is that the models of Brodsky's actions, from subversion of cultural and social situations to the use of everyday objects and materials in architectural design, produce complex meanings that require new contemporary forms of theorisation. More precisely, his architectural practices are experimental because they point out that the aim of art/architecture is not the production of an artwork or architectural object. Brodsky's practices aim to change the nature of architecture in the sense of achieving a new and "unknown aesthetic experience". 8

That said, I will focus on two architectural examples. The first example is that of the Vodka Pavilion (2004), the space for ceremonial drinking of vodka. The pavilion has free inner space and a small table with a vodka bowl. There is only enough space for two visitors to be inside it, give a toast and to drink vodka. The building itself was made of old window frames taken from an abandoned factory. Discarded window frames were fixed to a unique wooden frame, and then the entire structure was painted white.

The second example is a small round building set on the territory of the Ugra National Park in the Kaluga Region, the Nikola-Lenivets art/architecture park named Rotunda (2009). It was designed for the Archstoyanie festival in 2009. The walls of the entrance in the structure are framed with doors (taken from abandoned old houses) allowing a visitor to access it from any direction. The structure is fully constructed of wood waste and painted white.

The following chapters will deal with the conceptualisation of contemporary theoretical practices in order to further approach the textual analysis of the appropriation architecture phenomenon.

\section{APPROACHING THE QUESTION: WHAT IS THE ARTWORK?}

One of the most important contemporary problems of interpretation of architecture is how one can identify and understand architecture.

The term "artworld" was coined by American philosopher Arthur C. Danto in order to point out that the artwork is not only a material object before an observer, but in the words of Danto's famous statement, it is: 'To see something as art requires something the eye cannot descry - an atmosphere of artistic theory, a knowledge of the history of art: an artworld.' 
This definition was a great critique of Western-phenomenological aesthetics that was centered on the object (artwork). The artwork is a source of aesthetic experience. What Danto means is that we never come close to the very event, because we will always be blocked by an entire webs of meaning that surrounds what we recognise as an artwork. The artwork is not in itself and for itself, artwork is always a part of the artworld, or part of our habits, knowledge, communication practices, relationships in which this work occurs. The artworld is related to texts and cultural discourses that determine what we see. The artwork is the product of interpretation:

'Art exists in an atmosphere of interpretation and an artwork is thus a vehicle of interpretation. The space between art and reality is like the space between language and reality partly because art is a language of sorts, in the sense at least that an artwork says something, and so presupposes a body of sayers and interpreters who are in position, who define what being in position is, to interpret an object. There is no art without those who speak the language of the artworld, and who know enough of the difference between artworks and real things to recognize that calling an artwork a real thing is an interpretation of it, and one which depends for its point and appreciation on the contrast between the artworld and the real-world. ${ }^{10}$

In other words, the view of a building or any kind of artwork is part of a world that does not exist without discourse. More precisely, the artworld is an (architectural) object encompassed by various texts. If we apply Danto's observation to architecture, we come up with the following thesis: To observe something as architecture requires something the eye cannot descry - an atmosphere of architectural theory, more precisely: theory of architecture, theory of form, theory of style, philosophy, aesthetics, cultural studies, a knowledge of the history of architecture: the world of architecture as the artworld. ${ }^{11}$

\section{APPROACHING THE QUESTION: WHAT IS THE TEXT?}

In structuralism, a text is any closed and autonomous structure of signs. On the other hand, poststructuralism rejects structuralist insistence on the closeness, constraint and fixedness of the studied structure. ${ }^{12}$ In poststructuralism, the text denotes the open practice of working with signs that acquire meaning in relation to other signs or texts of culture. ${ }^{13}$ Poststructuralism emphasises the importance of dealing with the context. In other words, an architectural object 
(or situation, event, being, language, work of art) does not exist independently of the context in which it occurs, in which it is used, signified or understood, yet it is determined by that context. ${ }^{14}$

The concept of the transformation from work to text was theorised by French sociologist, writer, sociologist and literary critic Roland Barthes.$^{15} \mathrm{He}$ introduced some of the fundamental postulates in the understanding of art. The standpoint that the center of every art is merely an artwork, is replaced in Barthes's interpretation with the fact that the artwork is not something that is ultimate, but that the artwork changes under the conditions of exposure, viewing, reading, and identifying. Artwork is something that becomes text; the text passes through many different works creating a network of arts at the place of expectation of the finished piece. ${ }^{16}$ In his most radical form Barthes brings the thesis of the Death of the Author, ${ }^{17}$ creating the concept according to which the creator of the artwork or any kind of work is not the author himself. The creator of the work is the one who sees and reads the work. This thesis has fundamentally changed the concept that we are following the work from the creator to the source, showing that one creates a source linking the work with various cultural texts. That is why Louis Marin understands "reading" as a practice of: '[s]crutinising a graphic entirety and deciphering a text'. ${ }^{18}$ Applied to architecture, the following thesis can be made: Scrutinising a material form of the entirety of a building and deciphering a text.

For Barthes a text is 'multi-dimensional space in which are married and contested several writings, none of which is original: the text is a fabric of quotations, resulting from a thousand sources of culture. ${ }^{19}$ Very similar to this concept, Julia Kristeva introduces the notion of intertextuality, ${ }^{20}$ taken from a Russian philosopher and semiotician Mikhail Bakhtin's idea of dialogism. Intertextuality implies a semantic relation of: '(1) two or more texts; (2) text and visual artwork; (3) any human product and language and semiotic systems (natural language, literature, philosophy, ideology, painting). ${ }^{.21}$

The idea of intertextuality denotes that a particular text acquires meaning only through relations with other texts, which means that each text contains relocated elements of other texts. More precisely, by intertextuality Kristeva implies: 'In the space of a given text, several utterances, taken from other texts, intersect and neutralise one another. ${ }^{22}$ We compare one text with other texts of culture. In this regard, Kristeva speaks of the fact that the intertextuality is the exchange between texts in the creation of the meaning of one text. This means that we are relating an architectural object with other objects, that second or third object we are connecting with literary or religious, philosophical, political or some other 
text. In other words, with the notion of intertextuality she showed that we do not have isolated objects, but that we have objects that are inserted, placed in the real world and that the real world is full of texts that bear the endless meanings that will connect and transform these texts in their processes of understanding.

\section{FRAMING: EXPERIMENT AND READY-MADE}

The act of appropriation deals with some key artistic procedures in experimental art. The experimental is the term that signifies something which is not only different but completely opposed to traditional, conventional or academic artistic production. Italian theorist of avant-garde Renato Poggioli pointed out that: 'The experimental aspect of avant-garde art is manifested not only in depth, within the limits of a given art form, but also in breadth, in the attempts to enlarge the frontiers of that form or to invade other territories, to the advantage of one or both of the arts. ${ }^{23}$ Serbian philosopher Milan Damnjanović observed the experiment as 'an experiential verification of any, and even speculative causal ideas, in conditions that in principle overcome the laboratory situation ${ }^{24}$. In historical avant-gardes ${ }^{25}$ during the first half of the twentieth century, experiment receives not only affirmative value but also fundamental importance. In other words, the experiment is the feature characteristic of the avant-garde art. The conception and philosophy of ready-made emerges here as one of the key concepts.

Ready-made denotes an everyday object outside of artistic origin that had been taken over, re-signified, moved and exhibited as an artwork or as a segment of a larger whole of an artistic (architectural) work with or without additional material author intervention. The first ready-mades were realised by French artist Marcel Duchamp, who exhibited various items. ${ }^{26}$ Trying to see art as an intellectual game, Duchamp has shown an important situation in which one can be an artist not only if one creates an artwork using hands in the creative process, but also if something is observed, if it is chosen, if it is de-contextualised, and re-contextualised. According to Aleš Erjavec: 'It was only when art created according to or resembling that made by him (Duchamp) almost a century ago started to become the exclusive recognisable dominant trend of recent art that his work became an object of intense attention and was revealed as an early and paradigmatic instance of contemporary art. ${ }^{27}$

Ready-made is an artwork created by the artist's decision to mark or use the existing object outside of the world of art and place it in a gallery or museum and hence in the art world. 
Duchamp chooses the object: he is no longer the one who makes it, the one who produces it, and moves it into the public aesthetic regime of sensibility. About 30 years later, Ludwig Wittgenstein said: 'The meaning of a word is its use in the language. ${ }^{, 28}$ What Wittgenstein sets in relation to the language, if transferred to the world of the objects can mean: the meaning and function of one object is the use of that object in a particular socio-cultural context. ${ }^{29}$ In short, Duchamp transferred the object of the urinal from the everyday culture to the world of art.

\section{EXPANDING THE ARCHITECTURAL FIELD: DESIGN THROUGH APPROPRIATION}

Brodsky appropriates found materials as finished pieces. In other words, wooden window frame is an object with a non-architectural origin (or more precisely, is not of construction origin) which is taken over and re-signified, moved and exposed as the only architectural element in the design of the Vodka Pavilion. Using these kind of strategies and tactics, it turns out that Brodsky's motive was to explore a new way of architectural design. More precisely, in Brodsky's architectural production the experiment is submitted as a methodological tool to improve the process of architectural design. In one of his interviews, he said:

'I like to use simple things that I find. That is also something a lot of artists have done before me, and are doing right now, and will be doing after me. It's not like I'm inventing something new, but I like cheap materials, I love found objects, I like to give new life to something that was thrown away in the garbage. I find some of these things beautiful, so if I can use them in my art, I like to do it, or even use them sometimes in architectural pieces. ${ }^{30}$

Brodsky moves, reconstructs, multiplies, and sets an element, such as a window or a door, as the only element in the design of an architectural object. Duchamp does the same. He takes over something that is created for a practical purpose, changes its function, puts it in the field of senses, and confronts us with an object we observe in a different way. In both cases, the way of becoming artistic/ architectural is performed through appropriation.

The use of elements of non-constructional origin emphasises the fact that such objects have been introduced in the world of architectural design and their unusual role and position of exposition emphasise their artificiality in that world. This act is reminiscent of the procedure of ready-made because the material moved from the un-architectural-construction domain into architectural. It is, however, not ready-made because Brodsky does not take one window frame or one door 
and puts it in a space with the aim of naming these objects as architecture pieces or artwork. With the found materials Brodsky does not fully comply with the principle and philosophy of ready-made, but treats it as a "motif". This means that these elements, through repetition and multiplication, project their own architecture. With this approach, Brodsky shows that the activity in the field of architectural design is not only achieved through new production of various objects in the world, but also through the use of found objects and their use as a practice of transforming the contextual aspects of the objects itself.

These buildings combine the function of a building (the pavilion for drinking vodka and Rotunda as a viewpoint) with the use of avant-garde experimental techniques (the use of window frame, wood waste or old doors as design elements - thus pointing to the principle of ready-made). Nevertheless, the functionality of the object has the advantage in this relationship, and the principle of readymade appears only as an homage to avant-garde experimentation presented as a pure technique in the architectural form.

\section{CONCLUSION}

The paper has shown that Brodsky's architectural buildings appear as an architectural practice that applies various experimental techniques referring to historical avant-gardes (ready-made) only as a means in the architectural functionality. We can conclude that Brodsky's practices are not completely in agreement with the principles of ready-made, because of his relationship to the objects and found materials as a theme, not as a complete piece as it is set up by Duchamp. In other words, Brodsky does not exhibit a window frame as an object that does not belong to art, but as an object which has been placed in the world of art at the decision of the artist (which presents the main principle and the idea of ready-made), and only uses it as a building element in the design of an architectural project, relying on ready-made as avant-garde practice.

These projects shows that direct appropriation can be a justified method of architectural practices. In this way, the concept of architectural design is being expanded. Thus, Brodsky's architectural practice remains more an anomaly than a paradigmatic episode in the field of architecture.

These chapters were aimed at understanding architecture as a textual practice through a interweave of traces of philosophy, theory, and aesthetics of architecture and art with a mild reflection on Brodsky's architecture of appropriation. 
For more information, see: Lois Ellen Nesbitt, Brodsky and Utkin: The Complete Works (New York: Princeton Architectural Press, 2003).

Ines Weizman, "Citizenship”, in The SAGE Handbook of Architectural Theory, ed. by Greig Crysler et al. (London, California, New Delhi and Singapore: SAGE Publications Ltd., 2012), 107-121.

Alexander Rappaport, "Language and Architecture of Post-Totalitarianism," in Paper Architecture: New Projects from the Soviet Union, ed. by Heinrich Klotz (New York: Rizzoli, 1989), 11-17.

Nishat Awan, Tatjana Schneider and Jeremy Till eds., Spatial Agency: Other Ways of Doing Architecture (London: Routledge, 2011), 112.

Brodsky's major architectural works in the past two decades include: 95 Degrees, a restaurant in the Klyazma Reservoir near Moscow (2000), a timber scaffold connected by decks and ladders; the interior of the Apshu Café in Moscow (2003); Pavilion for Vodka Drinking Ceremonies (2004) in the Klyazma Reservoir near Moscow, constructed out of dilapidated window frames; Ice Pavilion, Klyazma Reservoir (2003); Country house in Tarussa (2006); Rotunda (2009), an oval shaped wooden building in the fields of Nikola-Lenivets, Kaluga Region, Russia; Rotunda II (2010) a 
wooden pavilion, part of the Russian "The Counterpoint: Russian Modern Art" exhibition in the Louvre, Paris, France; "Oval Shade”, Gorky Park (2012), made of timber and polymer resin; bus shelter in Krumbach (2014) composed as a wood tower; $101^{\text {st }} \mathrm{km}$ - Further Everywhere (2017) a temporary pavilion in London, England; Villa PO-2 (2018), an installation designed by Brodsky and Anton Timofeyev at the Archstoyanie annual festival, made out of PO-2 concrete fences; Pavilion for Chacha Ceremonies, Tbilisi, Georgia (2018).

See: Aleš Erjavec, "Postmodernism and the Post-Socialist Condition: 15 Year After (2003-2018)," Serbian Architectural Journal Vol. 9, No. 2 (2017), 156.

Miško Šuvaković, "Uvod - transdiciplinarna estetika, filozofija i teorija arhitekture," in Prolegomena za pojmovnik estetike, filozofije i teorije arhitekture, ed. by Miško Šuvaković (Beograd: Orion art, 2017), 15-59.

Arthur Danto, "The Artworld," in Philosophy Looks at the Arts. Contemporary Readings in Aesthetics, ed. by Joseph Margolis (Philadelphia: Temple University Press, 1987), 154-167.

Arthur Danto, "Artworks and Real Things," in Art and Philosophy. Readings in Aesthetics, ed. by W. E. Kennick (New York: St. Martin’s Press, 1979), 98-110.

Compare with: Miško Šuvaković, Estetika muzike - modeli, metode i epistemologije o/u modernoj i savremenoj muzici i instrumentima (Beograd: Orion art, 2016), 215.

Luka Bešlagić, Teorije eksperimetnalne tekstualne produkcije (Beograd: FMK, 2017), 102.

Miško Šuvaković, Diskurzivna analiza: prestupi i/ili pristupi “diskurzivne analize” filozofiji, poetici, estetici, teoriji i studijama umetnosti i kulture (Beograd: Orion art, 2010), 451.

Željka Pješivac, Ne/izrecivi prostor (Beograd: Orion art, 2018), 89.

Roland Barthes, "From Work to Text," in The Rustle of Language, trans. Richard Howard (Berkeley: University of California Press, 1989), 56-64.

Miško Šuvaković, op.cit., 430.

Roland Barthes, "The Death of the Author," in The Rustle of Language, trans. Richard Howard (Berkeley: University of California Press, 1989), 49-55.

“C'est parcourir du regard un ensemble graphique et c'est déchiffrer un texte" (fr.) from Louis Marin, "Éléments pour une sémiologie picturale," in Louis Marin, Études sémiologiques: Écritures, Peintures (Paris: Klincksieck, 1971), 17-43.

Roland Barthes, "The Death of the Author",op. cit., 53

See, for exemple: Marko Juvan, History and Poetics of Intertextuality, trans. Timothy Pogačar (West Lafayette, Indiana: Purdue University Press, 2008)

Miško Šuvaković, Pojmovnik teorije umetnosti (Beograd: Orion art, 2011), 135.

Julia Kristeva, Desire in Language: A Semiotic Approach to Literature and Art, trans. Thomas Gora, Alice Jardine and Leon S. Roudiez, ed. by Leon S. Roudiez (New York: Columbia University Press, 1980), 36 .

Renato Poggioli, The Theory of the Avant-garde, trans. Gerald Fitzgerald (Cambridge, Mass: Belknap Press of Harvard University Press), 133.

Milan Damnjanović, Problem eksperimentalne metode u estetici (Beograd: Institut društvenih nauka, 1965), 42.

German theorist of culture Peter Bürger places historical avant-garde as a specific artistic movement in the culture of the first half of the twentieth century, whose function is to reject the autonomy of art. Peter Bürger, Theory of the Avant-Garde, trans. M. Shaw (Minneapolis: University of Minesota Press, 1984).

Duchamp characteristic ready-mades are: Bicycle Wheel (1913 Bottle Dryer (1914) or Fontana (1917). Marcel Duchamp, "Apropo "ready-mades", Marcel Duchamp - Izbor tekstova, ed. by Zoran Gavrić and Branislava Belić (Bogovođa: Izdanje Z. Gavrić, 1995), 65. 
Aleš Erjavec, “Aesthetics: Philosophy of Art or Philosophy of Culture?," in Filozofski Vestnik št. 2, ed. by Aleš Erjavec (Ljubljana: ZRC SAZU, 2001), 7-20. Blackwell, 1953), 20.

Ana Dana Beroš, "We Can’t Predict What Will Suddenly Inspire Us", Oris Magazine, accessed February 262019 .Available at: http://www.oris.hr/en/oris-magazine/overview-of-articles/[116] we-cant-predict-what-will-suddenly-inspire-us, 1551.html

Adorno, Theodor. Aesthetic Theory. Translated by Robert Hullot-Kentor. New York: Continuum, 2004 .

Awan, Nishat, Schneider, Tatjana, and Till, Jeremy, eds. Spatial Agency: Other Ways of Doing Architecture. London: Routledge, 2011.

Barthes, Roland. "From Work to Text." In The Rustle of Language. Translated by Richard Howard, 56-64. Berkeley: University of California Press, 1989.

Barthes, Roland. "The Death of the Author." in The Rustle of Language, Translated by Richard Howard, 49-55. Berkeley: University of California Press, 1989.

Beroš, Ana Dana. "We Can’t Predict What Will Suddenly Inspire Us", Oris Magazine, accessed February 26 2019. Available at: http://www.oris.hr/en/oris-magazine/overview-of-articles/[116] we-cant-predict-what-will-suddenly-inspire-us, 1551.html

Bešlagić, Luka. Teorije eksperimetnalne tekstualne produkcije. Beograd: FMK, 2017.

Bürger, Peter. Theory of the Avant-Garde, Translated by M. Shaw. Minneapolis: University of Minesota Press, 1984. 
Damnjanović, Milan. Problem eksperimentalne metode u estetici. Beograd: Institut društvenih nauka, 1965.

Danto, Arthur. "Artworks and Real Things." In Art and Philosophy. Readings in Aesthetics, edited by W. E. Kennick, 98-110. New York: St. Martin's Press, 1979.

Danto, Arthur. "The Artworld." In Philosophy Looks at the Arts. Contemporary Readings in Aesthetics, edited by Joseph Margolis, 154-167. Philadelphia: Temple University Press, 1987.

Duchamp, Marcel. “Apropo 'ready-mades.” In Marcel Duchamp - Izbor tekstova, edited by Zoran Gavrić and Branislava Belić, 65. Bogovođa: Izdanje Z. Gavrić, 1995.

Erjavec, Aleš. “Aesthetics: Philosophy of Art or Philosophy of Culture?” In Filozofski Vestnik št. 2, edited by Aleš Erjavec, 7-20. Ljubljana: ZRC SAZU, 2001.

Erjavec, Aleš. "Postmodernism and the Post-Socialist Condition: 15 Year After (2003-2018)", Serbian Architectural Journal Vol. 9, No. 2 (2017), 153-162.

Juvan, Marko. History and Poetics of Intertextuality, Translated by Timothy Pogačar. West Lafayette, Indiana: Purdue University Press, 2008.

Kristeva, Julia. Desire in Language: A Semiotic Approach to Literature and Art, Translated by Thomas Gora, Alice Jardine and Leon S. Roudiez, edited by Leon S. Roudiez. New York: Columbia University Press, 1980.

Marin, Louis. "Éléments pour une sémiologie picturale." In Louis Marin, Études sémiologiques: Écritures, Peintures, 17-43. Paris: Klincksieck, 1971.

Nesbitt, Lois Ellen. Brodsky and Utkin: The Complete Works. New York: Princeton Architectural Press, 2003.

Pješivac, Željka. Ne/izrecivi proctor. Beograd: Orion art, 2018.

Poggioli, Renato. The Theory of the Avant-Garde. Translated by Gerald Fitzgerald. Cambridge, Mass.: Belknap Press of Harvard University Press, 1968.

Rappaport, Alexander. “Language and Architecture of Post-Totalitarianism.” In Paper Architecture: New Projects from the Soviet Union, edited by Heinrich Klotz, 11-17. New York: Rizzoli, 1989.

Šuvaković, Miško. "Uvod - transdiciplinarna estetika, filozofija i teorija arhitekture." In Prolegomena za pojmovnik estetike, filozofije i teorije arhitekture, edited by Miško Šuvaković, 15-59. Beograd: Orion art, 2017.

Šuvaković, Miško. Diskurzivna analiza: prestupi i/ili pristupi “diskurzivne analize” filozofiji, poetici, estetici, teoriji i studijama umetnosti i culture. Beograd: Orion art, 2010.

Šuvaković, Miško. Estetika muzike - modeli, metode i epistemologije o/u modernoj i savremenoj muzici i instrumentima. Beograd: Orion art, 2016.

Šuvaković, Miško. Pojmovnik teorije umetnosti. Beograd: Orion art, 2011.

Weizman, Ines. "Citizenship." In The SAGE Handbook of Architectural Theory, edited by Greig Crysler, Stephen Cairns, Hilde Heynen, 107-121. London, California, New Delhi and Singapore: SAGE Publications Ltd., 2012.

Wittgenstein, Ludwig. Philosophical Investigations. Translated by G.E.M. Anscombe. Oxford: Basil Blackwell, 1953. 


\section{ESTETIKA ODRŽIVOSTI: ARHITEKTURA KAPSULE U GRADU I U PRIRODI Peter Šenk}

Arhitektura najmanjih mesta za stanovanje je u poslednje vreme izuzetno popularna tema. Kada su najmanja mesta za stanovanje kompaktna, dobro opremljena, povezana na mrežu, strukturno, funkcionalno i vizuelno prepoznata kao jedna stvar, privremena i pokretna ili prenosiva, mogu se označiti kao arhitektura kapsule. Budući da su po svojoj prirodi privremena, ova najmanja mesta za stanovanje, skloništa, redizajnirane kontejnerske jedinice, posebne tehnološke konstrukcije, paraziti i druge manifestacije koncepta kapsula obuhvataju logiku tehnoloških objekata s izrazitim arhitektonskim izrazom. To je, istovremeno, manifestacija pravila održivog dizajna, održive arhitekture i održivosti uopšte. U ovom kontekstu slučaj najmanjih mesta za stanovanje pokazuje svoju razliku u odnosu na druge održive arhitektonske pristupe i estetike. Podredjuje uopšteno održive pristupe sa izraženim značajem lokaliteta unutar globalnih sila, obično se oslanjajući na kontekst - lokaciju, lokalnu kulturu i karakteristike životne sredine itd. Estetski režim trenutnih, promenljivih, kontekstualnih i autonomnih arhitektonskih struktura se može posmatrati kao estetika drugosti, koja ih povezuje sa nasledjem egzistencijalnih eksperimenata modernog pokreta, novim brutalizmom, radikalnim eksperimentima 1960-ih i drugim avangardnim i neoavangardnim praksama dvadesetog veka, ali čvrsto postavljenim u kontekstu individualizovane, neodredjene, raspršene i dvosmislene savremenosti.

KLJUČNE REČI: ESTETIKA PROMENE, KAPSULE, NAJMANJA MESTA ZA STANOVANJE, MINIMALAN TRAG, DRUGOST, ESTETIKA ODRŽIVOSTI

\section{ESTETIKA I KULTUROLOŠKI ASPEKTI BAUHAUSA: \\ KA NOVOJ KONCEPCIJI}

\section{Christiane Wagner}

Ovaj članak pokriva nove mogućnosti Bauhaus pogleda na svet: stvaranje novih oblika za prikazivanje ljudskih ideala kroz fokus na estetiku i tehnologiju, u kombinaciji sa Nimajerovim (Niemeyer) uticajem na arhitekturu i dizajn. Novi stilovi i oblici nastali su kao izdanci Bauhausa, prenoseći vrednosti svake kulture kroz izgradnju kolektivne „slike“ sveta. Bauhaus današnjice izražava industriju kulture, dijalektički razmatrajući inovaciju i primenjenu umetnost kao put od modernog dizajna industrijske revolucije do „eko dizajna“. U tom smislu, Bauhaus je još uvek značajan po svojoj ulozi, povezujući umetnost, tehnologiju i industriju. Inovacija kao dinamično odredjivanje trenutka, prisutna u svim epohama, se shvata kao moćna sila za održavanje tradicije. Pored hronološkog zapisa o uticaju Bauhausa, razmatraju se i značajni Nimajerovi projekti. Na kraju su prikazane dve perspektive ,raskola“ izmedju arhitekture i tehnologije. Prva perspektiva se odnosi na ljudsku sposobnost stvaranja modela u arhitektonskoj praksi za usvajanje kao konfiguraciju prostora. Druga se odnosi na evoluciju tehnologija koje vode do toga da zamišljeno postaje stvarnost kroz vreme, kako je to opisao Hegel (1823).

KLJUČNE REČI: IZRADA PO MERI, TEHNOLOŠKI RAZVOJ, PROSTOR-VREME, NOVI OBLICI

\section{KLASIČNA ARHITEKTURA U OKVIRU KANTOVSKE ESTETIKE: IZMEĐU LIOTARA I RANSIJERA}

\section{Helen Tatla}

Potencijal koji je svojstven klasičnoj arhitekturi da predstavlja glavni arhitektonski izraz zapadne kulture budući da je grčka antika nastala zbog svog dualnog karaktera: iako izvire iz iskonskog jedinstva stvari izraženih mitom i religijom u arhaičnim vremenima, ona dobija svoj završni oblik u petom veku p. n. e., kao simbol demokratije i harmonične artikulacije sveta na osnovu filozofskog mišljenja. 
Postavljajući avangardnu umetnost u sferu kantovske uzvišenosti, Žan Fransoa Liotar (JeanFrancois Lyotard) se fokusira na nemogućnost apsolutnog odnosa razuma i percepcije ili između razmišljanja i slike, u savremenosti. On smatra da se u slučajevima kada se to dogodi radjaju politička čudovišta. On povezuje postmoderne izraze klasicizma u arhitekturi sa Frojdovim „Tumačenjem snova“" i kantovskom lepotom.

Pristup Žaka Ransijera (Jacques Ranciere) kantovstvu na osnovu estetskog razmatranja modernosti suprotan je onome koji je predložio Liotar. Umesto uzvišenog, Ransijer povezuje lepo s pukotinom izmedju razmišljanja i percepcije. U tom pogledu, fragmenti prošlosti mogu da podstaknu kreativni proces u sadašnjosti.

Cilj ovog istraživanja je da doprinese dijalogu o obnovljenom pristupu ulozi klasicizma u arhitekturi danas.

KLJUČNE REČI: KLASIČNA ARHITEKTURA, KANT, LIOTAR, MODERNOST, POLITIKA, POSTMODERNOST, RANSIJER

\section{FLUIDNO STANJE ARHITEKTURE}

\section{Bojana Jerković-Babović}

Ovaj rad se bavi promenama u kriterijumima arhitektonske estetike, transformacija statičnih u dinamične vrednosti podjednako figurativnih i nefigurativnih aspekata savremene arhitekture i njenog konteksta. Fluidno stanje arhitekture odnosi se na prepoznavanje konstantne promenljivosti koja se manifestuje u relacijama arhitekture i savremenom kultuloroškog konteksta globalizacije. Savremeni kontekst dinamizuje perceptivna iskustva svakodnevnice, uslove života i načine prostornih aproprijacija. U skladu sa tim, novi fenomeni umreženosti koji se manifestuju na informacionim, komunikacionim i prostornim nivoima transformišu grad i arhitekturu u konstantne procese tokova, kojima se njihovi elementi dematerijalizuju u nove fluidne, promenljive karakteristike. Vredosti arhitektonske estetike istovremeno se transformišu ka afirmaciji dogadjaja i efekata naspram statične formale celine, od objektivnih do intersubjektivnih estetskih prostornih iskustava.

Ovaj rad se bazira na hipotezi da savremenu arhitekturu karakteriše gubitak singularnosti objekta u odnosu sa uslovima konteksta i asimilacija karaktera pojedinačnih elemenata u fluidni karakter celine. Na taj način, arhitektonske projektantske principe karakteriše disperzija disciplinarnih granica i granica unutrašnjosti i spoljašnjosti, hibridnost i gubitak tipoloških definicija. Ovaj rad prikazuje kako dematerijalizacija arhitektonskih vrednosti transformiše savremeni arhitektonski prostor u kompleksan dinamički sistem infrastrukture, tokova, događaja i efekata.

KLJUČNE REČI: ARHITEKTONSKA ESTETIKA, ARHITEKTONSKO PROJEKTOVANJE, ESTETSKO ISKUSTVO, DINAMIČKE VREDNOSTI, FLUIDNOST, GLOBALIZACIJA

\section{KINEMATOGRAFIJA I ARHITEKTURA: MODERNA PERCEPCIJA Sônia Campaner Miguel Ferrari}

Esej Valtera Benjamina (Walter Benjamin) o bioskopu objašnjava njegove prognostičke vrednosti. Dok je pisao ovaj članak, njegova kritika kapitalističkog načina produkcije pokazala je pravac u kojem kapitalizam napreduje: ka sve većoj eksploataciji proletarijata, ali i ka svom vlastitom padu. Nas zanimaju ove prognoze koje potvrdjuju transformaciju umetnosti i njene funkcije, a koja našu pažnju usmeravaju na gubitak transcedencije i opadanja aure umetničkog dela. One u isto vreme pokazuju mogućnosti kojima se potvrđuje kontinuitet umetnosti koja ima drugačiju ulogu i dislokacija aure. Oblik umetnosti koji je pogodan za ovakvo razmišljanje je kinematografija i paralela koju je filozof povukao izmedju kinematografije i arhitekture. Namera nam je da se osvrnemo na ovu paralelu i urbane intervencije kao umetničke oblike estetske modernosti: to 
jest, kao proizvode ove modernosti koji istovremeno ukazuju na način koji nam je dat i shvaćen. Takodje ćemo se osvrnuti i na indikacije bioskopa i pozorišta kao načina da se prevazidju telesne odrednice koje nam se nameću.

KLJUČNE REČI: ARHITEKTURA, BIOSKOP (KINEMATOGRAFIJA), MODERNA UMETNOST, MODERNA PERCEPCIJA, URBANIZAM

\section{AUTORSTVO I JEZIK U KNJIGAMA SAVREMENIH ARHITEKATA}

\section{Deniz Balık Lökçe}

Ovaj rad se bavi ispitivanjem teorijskih, grafičkih i materijalnih dimenzija savremene kulture štampe u arhitekturi sa fokusom na po jedno delo iz različitih evropskih praksi. Knjiga savremenog arhitekte posmatra se kao spekulativni i diskurzivni predmet dizajna. Mišel Fuko (Michel Foucault), posebno u svojim delima, Šta je autor? (1969) i Arheologija znanja (1972), kritikuje to da se prilikom izrade opusa jednog autora alternativni i neklasifikovani žanrovi izostavljaju iz domena, a tekstovi koji se vezuju za jedno ime pripadaju sistemu homogenosti, veze i recipročnog objašnjenja. Ipak, knjiga savremenog arhitekte proširuje granice žanrova tako što je sačinjena od nekonvencionalnih materijala, poput muzičkih nota, umetničkih fotografija, slika, tehničkih i naučnih dijagrama, zvaničnih izveštaja, gradjevinskih propisa, novinskih članaka i reklama, a takođe i od kombinacije tekstova i fotografija saradnika, partnera, klijenata i korisnika, a ne samo kao produkt jednog autora. Ovaj rad se bavi tumačenjem korišcenja različitih oblika grafičke naracije i spajanja nove terminologije i žargona kao doprinosa moći jezika i diskurzivnoj formaciji.

KLJUČNE REČI: ARHITEKTONSKI MEDIJI, ARHITEKTONSKA MONOGRAFIJA, KNJIGA, FUKO, ŽANR, KULTURA ŠTAMPE, AUTOR, TEKST

\section{ARHITEKTURA KAO TEKSTUALNI FENOMEN: APROPRIJACIUSKE ARHITEKTONSKE PRAKSE ALEKSANDRA BRODSKOG Boško Drobnjak}

Tekst analizira arhitekturu nastalu aproprijacijom postojećih materijala fokusirajući se na strategije intertekstualnosti. Rad zastupa tezu da značenje arhitektonskog objekta ne proizlazi iz njega samog ili njegovih poetskih koncepata, već iz njegovih odnosa sa drugim arhitektonskim objektima, drugim umetničkim delima kao tekstovima, kulturalnim tekstovima i svakodnevnim životnim praksama. Cilj rada jeste da se pokažu različiti teorijski problemi teorije arhitekture i umetnosti koji kao mreža uodnošenih tekstova kulture okružuju arhitektonsku produkciju Aleksandra Brodskog (Alexander Brodsky). Za metod rada je karakteristično operisanje sa različitim i raznorodnim teorijskim konceptima, uzimajući odabrane studije slučaja (Votka paviljon i Rotunda) arhitekture Brodskog u okviru koje je rad koncipiran kao interdisciplinarna studija.

KLJUČNE REČI: ALEKSANDAR BRODSKI, APROPRIJACIJA, SVET UMETNOSTI, EKSPERIMENTALNA ARHITEKTURA, READY-MADE, TEKST

\section{PITER AJZENMAN I MOGUĆNOST ESTETSKOG FORMALIZMA \\ Amund M. Rolfsen}

Formalna razmatranja predstavljaju srž aspekta rada Piter Ajzenmana (Peter Eisenman). Može se tvrditi da su ona jedina dosledna tema njegovog rada, i zasnivaju se na konceptu da je arhitektura posredovanje izmedju otelovljenog unutrašnjeg sveta ljudskih bića i spoljnog fizičkog sveta koji naseljavamo. Ajzenman tako daje „konceptualnu“, a ne percepcijsku osnovu, pri čemu su univerzalni formalni odnosi važniji od čulnih aspekata. Na taj način arhitektura ostaje kao 